\title{
Epidemiological, Clinical, Therapeutic and evolutionary Aspects of Children Living with HIV in Guédiawaye, Senegal
}

\section{Jean Baptiste Niokhor Diouf 1,2*, Ndèye Marème Sougou ${ }^{3}$, Cheikh Tidiane Tall², Mariama Kane ${ }^{1}$, Louis Philippe Sarr ${ }^{1}$, Ousmane Ndiaye ${ }^{4}$}

${ }^{1}$ Pediatric Department, Roi Baudouin Hospital, Guédiawaye, Senegal

${ }^{2}$ Saint Christopher Iba Mar Diop School of Medicine-Pharmacy-Dental, Dakar, Senegal

${ }^{3}$ Department of Public Health, Institute of Health and Development, (ISED), Cheikh Anta Diop University, Dakar, Senegal

${ }^{4}$ Albert Royer National Children's Hospital, Dakar, Senegal

Email: *jeanniokhor@gmail.com

How to cite this paper: Diouf, J.B.N., Sougou, N.M., Tall, C.T., Kane, M., Sarr, L.P. and Ndiaye, O. (2021) Epidemiological, Clinical, Therapeutic and evolutionary Aspects of Children Living with HIV in Guédiawaye, Senegal. Open Journal of Pediatrics, 11, 738-748.

https://doi.org/10.4236/ojped.2021.114068

Received: October 18, 2021

Accepted: December 6, 2021

Published: December 9, 2021

Copyright $\odot 2021$ by author(s) and Scientific Research Publishing Inc. This work is licensed under the Creative Commons Attribution International License (CC BY 4.0).

http://creativecommons.org/licenses/by/4.0/

\begin{abstract}
Introduction: HIV infection in children is a major public health problem. The objective of this study carried out in the paediatric department of the Centre Hospitalier Roi Baudouin de Guédiawaye, was to evaluate the epidemiological, clinical, therapeutic and evolutionary aspects of a cohort of children with HIV over a 15-year period and to determine the factors associated with discontinuation of treatment and transition to second-line treatment. Patients and Methods: This was a descriptive and analytical cross-sectional study from August 2004 to December 2019 at the Centre Hospitalier Roi Baudouin de Guédiawaye. Through this study, age at diagnosis, current age, gender, orphan status, therapeutic aspects, status announcement and evolution were evaluated. A total of 129 patient records were studied over a 15-year period (2004-2019). HIV-positive children with profile I represented $93.8 \%$ and there was a male predominance with a sex ratio of 1.43 . The current mean age of the children was $12.2 \pm 4.5$ and the median was 14 years. Fatherless and motherless children represented $24.0 \%$ and $20.2 \%$, respectively, while both fatherless and motherless children represented $11.6 \%$. The mean age at the start of ARV treatment was $7.6 \pm 4.3$ years and the median was 7.5 years. The mean age at the start of second-line treatment was 13.7 years with a standard deviation of 2.6 while the median was 13 years. AZT + 3TC + NVP was the most commonly used combination (29.5\%) followed by TDF + FTC + NVP (26.2\%). The mean age at treatment discontinuation was $13.3 \pm 4.3$ years while the median was 15 years. More than half of the children (57.0\%) $(\mathrm{N}=69)$ were aware of their status. Factors associated with discontinuation
\end{abstract}


were gender ( $\mathrm{p}$ value $=0.025$ and $\mathrm{OR}=3.2)$, orphan status $(\mathrm{p}$ value $=0.027$ and $\mathrm{OR}=3.0$ ) and follow-up time greater than 10 years ( $\mathrm{p}$ value $=0.013$ and $\mathrm{OR}=5.6$ ). The mortality rate was $3.9 \%$. Factors associated with transition to second-line treatment were year of inclusion ( $\mathrm{p}$ value $=0.001$ and $\mathrm{OR}=15.6$ ), age group ( $\mathrm{p}$ value $=0.001$ and $\mathrm{OR}=19.2$ ), orphan status ( $\mathrm{p}$ value $=0.040$ and $\mathrm{OR}=2.6$ ), treatment regimen ( $\mathrm{p}$ value $=0.019$ and $\mathrm{OR}=5.7$ ), duration of ARV treatment ( $\mathrm{p}$ value $<0.001$ and $\mathrm{OR}=38.0$ ) and announcement ( $\mathrm{p}$ value $=0.002$ and $\mathrm{OR}=4.7)$. Conclusion The cohort of HIV-infected children followed up in Guédiawaye remains dominated by adolescents. Orphan status, announcement of status and duration of follow-up are associated with transition to second-line treatment and treatment discontinuation.

\section{Keywords}

Children, HIV, Guédiawaye, Senegal

\section{Introduction}

HIV infection in children is a major public health problem. The United Nations Aids Programme (UNAIDS) estimates that 37.7 million (30.2 million - 45.1 million) people were living with HIV in 2020 worldwide [1]. In 2020, the number of people living with HIV in Senegal was 39,000 (35,000 - 44,000), including 3,900 (3300 - 4600) children aged 0 - 14 years [2]. Like the international community, Senegal is committed to reaching the UNAIDS target of the "Three 90s", i.e. "90-90-90" in 2014. The TATARSEN strategy (Test all, Treat all and Retain in Senegal) is based on the early treatment of HIV, which has not only a very positive impact at the individual level by considerably improving the duration and patient quality of life but also at the collective level by significantly reducing the transmission of the virus within the community and allowing the suppression of the virus replication in the maximum number of patients. Thus, encouraging results have been recorded, particularly a steady decline in new infections and a significant increase in the number of people on ARV treatment (ARVT), which represented $51.6 \%$ of all people living with HIV (PLHIV) in 2016, i.e. an increase of $4.4 \%$ in 4 years [3]. To maintain this momentum, it is important to properly identify the characteristics of the populations at the operational level. The objective of this study carried out in the paediatric department of the Centre Hospitalier Roi Baudouin de Guédiawaye, is to evaluate the epidemiological, clinical, therapeutic and evolutionary aspects of a cohort of children with HIV over a 15 -year period and to determine the factors associated with treatment discontinuation and transition to second-line treatment.

\section{Materials and Methods}

This was a descriptive and analytical cross-sectional study over a period from August 2004 to December 2019 at the Centre Hospitalier Roi Baudouin de 
Guédiawaye. This facility is one of the first sites to decentralize HIV management at the national level, thus explaining why it has a very large cohort of patients, both adults and children. The paediatric department, which is one of the seven medical departments in the structure, ensures, along with the pharmacy, laboratory and social services, the follow-up of HIV-infected children. The management of HIV-infected children was integrated into the other activities of the department. All children infected and followed up in the department were included in the study. Children with incomplete records were excluded from the study. The following variables were studied:

- Age at diagnosis has broken down as follows: before 1 year, between 1 and 5 years, between 5 and 10 years, after 10 years;

- Current age has broken down as follows: before 1 year, between 1 and 5 years, between 5 and 10 years, after 10 years;

- Sex;

- Orphan status:

- Living parents;

- Fatherless;

- Motherless;

- Both parents deceased;

- Profile: HIV 1 or HIV 2;

- Therapeutic aspects: Treatment regimen; treatment protocol; treatment duration. The treatment duration was assessed before 2017 and after 2017. This benchmark corresponded to the application of the "Test and Treat" guideline in Senegal.

- Status announcement;

- Progress: Lost to follow-up, followed up, transferred, deceased.

Data collection was based on the use of patients' medical records. Data entry was carried out with Epi Info version 7 software. The analysis was carried out with SPSS software version 22 and consisted of two parts, namely descriptive analysis and analytical analysis.

In the descriptive analysis, the qualitative variables were described in terms of numbers and percentages and the quantitative variables in terms of mean with standard deviation, extremes and median.

The bivariate analysis was to make a comparison between the therapy discontinuation and the other variables on the one hand and the transition to L2 and the other variables on the other hand. The Chi-square test was used for percentage comparison. The difference was statistically significant when the p-value was strictly less than 0.05 . The ORs and their $95 \%$ confidence intervals showed the strength of the relationship.

\section{Results}

A total of 129 patient records were studied over a 15-year period (2004-2019). HIV-positive children with profile I represented 93.8\% $(\mathrm{N}=121)$ and profile II, 
$6.2 \%(\mathrm{~N}=8)$. There was a male predominance with $58.9 \%(\mathrm{~N}=76)$. The sex ratio was 1.43 . The mean age of the children at diagnosis was $5.0 \pm 3.5$ years with extremes of 0 and 16 years. The median was 4 years. The age group 1-4 years was more representative (Figure 1 ).

The current mean age of the children was $12.2 \pm 4.5$ with extremes of 1 and 20 years. The median was 14 years. The age range of 11 - 15 years was more representative (Figure 2).

Fatherless and motherless children accounted for $24.0 \%$ and $20.2 \%$ respectively, while both fatherless and motherless children accounted for $11.6 \%$ (Table 1).

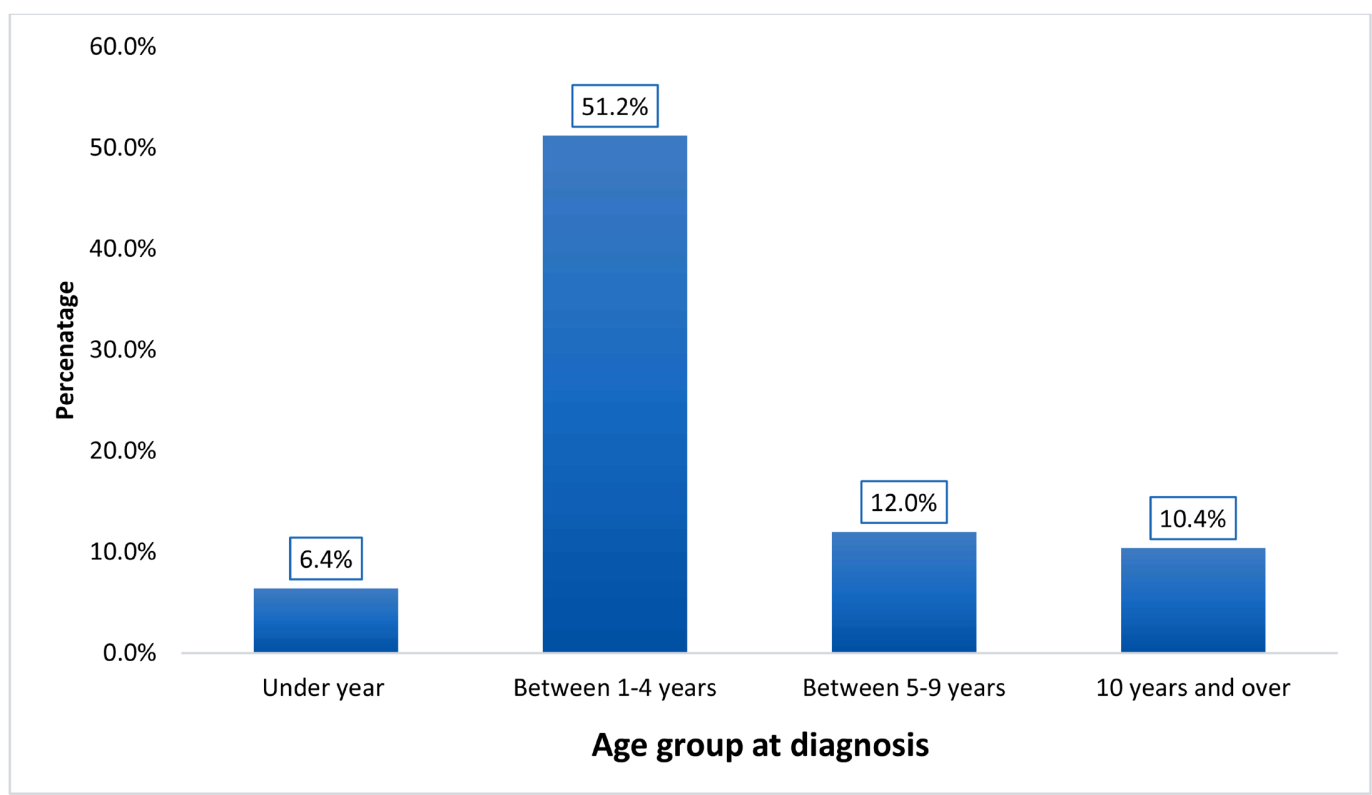

Figure 1. Distribution of patients by age group at diagnosis.

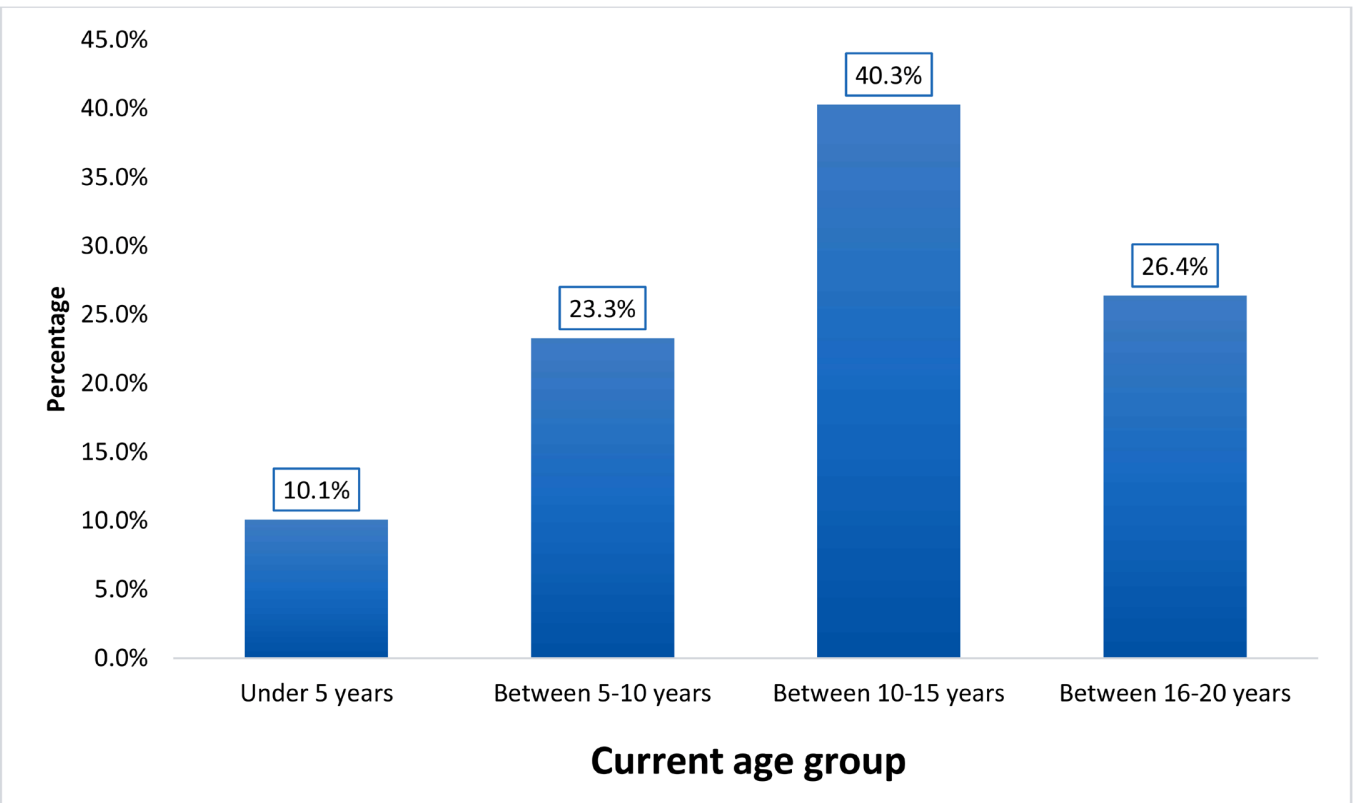

Figure 2. Distribution of patients by current age. 
The mean age at the start of ARV treatment was $7.6 \pm 4.3$ years with extremes of 0 and 17.6 years. The median was 7.5 years. Prior to 2017, the mean time from initial examination to ARV treatment initiation was $3.3 \pm 3.6$ years with extremes of 0 and 13 years. The median was 2 years. After 2017, the mean time from initial examination to ARV treatment initiation was $1 \pm 2$ months with extremes of 0 and 6 months. The median was 0.3 months.

The mean time from diagnosis to the last contact was 7.6 years with a standard deviation of 4.4 and extremes of 0.04 and 15.3 years. The median was 8.2 years. The majority of children, $78.3 \%,(\mathrm{~N}=94)$ were on first-line while $21.8 \%$ $(\mathrm{N}=28)$ of children were on second-line. The mean age of starting second-line treatment was 13.7 years with a standard deviation of 2.6 and extremes of 8.8 and 19.5 years. The median was 13 years. The mean time from inclusion to L2 initiation was 8.2 years with a standard deviation of 3.8 and extremes of 2.1 and 15.1 years. The median was 8.7 years. The mean time from ARV treatment initiation to L2 initiation was 6.2 years with a standard deviation of 3.8 and extremes of 0 and 15.1 years. The median was 5.9 years.

$\mathrm{AZT}+3 \mathrm{TC}+\mathrm{NVP}$ was the most commonly used combination (29.5\%) followed by TDF + FTC + NVP (26.2\%) (Table 2).

The mean age at treatment discontinuation was $13.3 \pm 4.3$ years with extremes of 7 and 18.7 years. The median was 15 years.

Table 1. Distribution of children by orphan status.

\begin{tabular}{ccc}
\hline Vital status of parents & Numbers & Percentage \\
\hline Living parents & 57 & 44.2 \\
Fatherless & 31 & 24.0 \\
Motherless & 26 & 20.2 \\
Both fatherless and motherless & 15 & 11.6 \\
Total & 129 & 100.0
\end{tabular}

Table 2. Distribution of children by current regimen.

\begin{tabular}{ccc}
\hline Current regimen & Numbers & Percentage \\
\hline AZT $+3 \mathrm{TC}+\mathrm{NVP}$ & 36 & 29.5 \\
$\mathrm{TDF}+\mathrm{FTC}+\mathrm{EFV}$ & 32 & 26.2 \\
$\mathrm{TDF}+3 \mathrm{TC}+\mathrm{LPV} / \mathrm{r}$ & 12 & 18.0 \\
$\mathrm{TDF}+3 \mathrm{TC}+\mathrm{EFV}$ & 12 & 9.8 \\
$\mathrm{AZT}+3 \mathrm{TC}+\mathrm{LPV} / \mathrm{r}$ & 8 & 6.6 \\
$\mathrm{AZT} / 3 \mathrm{TC} / \mathrm{EFV}$ & 7 & 5.7 \\
$\mathrm{ABC}+3 \mathrm{TC}+\mathrm{LPV} / \mathrm{r}$ & 4 & 3.3 \\
$\mathrm{TDF}+\mathrm{FTC}+\mathrm{LPV} / \mathrm{r}$ & 1 & 0.8 \\
Total & 122 & 100.0 \\
\hline
\end{tabular}


The mean time from initiation to cessation of ARV treatment was $5.4 \pm 2.3$ years with extremes of 0.8 and 9.1 years. The median was 5.9 years.

More than half of the children, i.e. 57.0\%, $(\mathrm{N}=69)$ had been informed of their status. The mean age at the announcement time was $13.9 \pm 1.8$ years with extremes of 11.0 and 19 years. The median was 13.7 years.

More than half of the children $(68.4 \%)$ were under 15 years old at the announcement time.

The mortality rate was $3.9 \%$. Lost to follow-up and transfer rates were $3.9 \%$ and $1.6 \%$, respectively.

Factors associated with therapeutic discontinuation were gender $(\mathrm{OR}=3.2$, 95\% CI (1.2 - 9.2), $\mathrm{p}=0.025)$, parental vital status (OR = 3.0, 95\% CI (1.1 - 7.9), $\mathrm{p}=0.027)$ and follow-up duration $(\mathrm{OR}=5.6,95 \% \mathrm{CI}(1.3-25.4), \mathrm{p}=0.013)$.

Factors associated with transition to second-line were: year of inclusion ( OR $=15.6,95 \% \mathrm{CI}(2.5-147), \mathrm{p}=0.001)$, age group $(\mathrm{OR}=19.2,95 \% \mathrm{CI}(2.5-147)$, $\mathrm{p}=0.001)$, orphan status $(\mathrm{OR}=2.6,95 \% \mathrm{CI}(1.1-6.7), \mathrm{p}=0.040)$, regimen $(\mathrm{OR}$ $=5.7,95 \% \mathrm{CI}(1.3-45.1), \mathrm{p}$ value $=0.019), \mathrm{ARV}$ treatment duration $(\mathrm{OR}=38.0$, $95 \% \mathrm{CI}(4.5-100), \mathrm{p}<0.001)$, and announcement $(\mathrm{OR}=4.7,95 \% \mathrm{CI}(1.6-13.4)$, $\mathrm{p}=0.002)($ Table 3$)$.

\section{Comment}

The aim of this study was to determine the epidemiological, clinical, therapeutic and evolutionary aspects of a cohort of children with HIV over a 15-year period and to determine the factors associated with treatment discontinuation and transition to second-line treatment. Thus, 129 children were enrolled. The mean age of the children at diagnosis was $5.0 \pm 3.5$ years and the median was 4 years. The mean age is variable in the different series in the literature. Our results corroborate those of Dirajlal-Fargo and al with a mean age of 2.8 years [4]. However, Bhattacharya SD and al found a higher average age of 6 years [5]. The average age at diagnosis was higher in the older studies, which may be explained by the fact that diagnosis is nowadays made earlier. Similarly, the current mean age of children was $12.2 \pm 4.5$ years with extremes of 1 and 20 years. Our results differed from those of d'Almeida and al who found a mean age of 7.4 years [6]. In our series, children aged 11 - 15 years and 16 - 20 years represented $40.3 \%$ and $26.4 \%$, respectively, i.e. a total of $66.7 \%$. This indicates the predominance of adolescents in the cohort. It is, therefore, necessary to set up a transition programme towards adult cohorts and to raise awareness of prevention measures, particularly abstinence and safe sex, in the follow-up of these children. Among young people, the risk of acquiring HIV infection is closely linked to the age of first sexual intercourse. Abstinence and delaying sexual debut are among the main goals of HIV prevention efforts among young people [7]. All HIV services for young people must involve young people living with HIV in their planning and delivery of services. Otherwise, the risk of second-line treatment or treatment failure remains. In our series, children aged 10 years and older were 19.2 
Table 3. Factors associated with drug discontinuation and transition to second-line therapy.

\begin{tabular}{|c|c|c|c|c|c|c|c|}
\hline \multirow{2}{*}{ Associated factors } & \multicolumn{2}{|c|}{ Yes } & \multicolumn{2}{|c|}{ No } & \multirow{2}{*}{ Total } & \multirow{2}{*}{$\mathrm{p}$ Value } & \multirow{2}{*}{$\begin{array}{c}\text { OR } \\
(95 \% \mathrm{CI})\end{array}$} \\
\hline & $\mathbf{N}$ & $\%$ & $\mathbf{N}$ & $\%$ & & & \\
\hline \multicolumn{8}{|c|}{ Therapeutic discontinuation } \\
\hline Sex & & & & & & 0.025 & \\
\hline Female & 5 & 9.4 & 48 & 90.6 & 53 & & Ref \\
\hline Male & 19 & 25.0 & 57 & 75.0 & 76 & & $3.2[1.2-9.2]$ \\
\hline Living parent & & & & & & 0.027 & \\
\hline No & 14 & 25.0 & 42 & 75.0 & 56 & & $3.0[1.1-7.9]$ \\
\hline Yes & 7 & 10.1 & 62 & 89.9 & 69 & & Ref \\
\hline Follow-up duration & & & & & & 0.013 & \\
\hline Under 10 years & 19 & 22.4 & 66 & 77.6 & 85 & & $5.6[1.3-25.4]$ \\
\hline 10 years and over & 2 & 4.9 & 39 & 95.1 & 41 & & Ref \\
\hline \multicolumn{8}{|c|}{ Transition to second-line } \\
\hline \multicolumn{8}{|l|}{ Age group } \\
\hline 10 years or less & 1 & 2.3 & 42 & 97.7 & 43 & 0.001 & Ref \\
\hline Over 10 years & 27 & 31.4 & 59 & 68.6 & 86 & & $19.2[2.5-147]$ \\
\hline \multicolumn{8}{|l|}{ Living parents } \\
\hline Yes & 7 & 12.5 & 49 & 87.5 & 56 & 0.040 & Ref \\
\hline No & 19 & 27.1 & 51 & 72.9 & 70 & & $2.6[1.1-6.7]$ \\
\hline \multicolumn{8}{|l|}{ Regimen } \\
\hline $\mathrm{ABC}+3 \mathrm{TC}+\mathrm{LPV} / \mathrm{r}$ & 4 & 100.0 & 0 & 0.0 & 4 & 0.038 & Ind \\
\hline $\mathrm{TDF}+3 \mathrm{TC}+\mathrm{LPV} / \mathrm{r}$ & 18 & 82.8 & 4 & 18.2 & 22 & 0.019 & $5.7[1.3-45.1]$ \\
\hline $\mathrm{TDF}+\mathrm{FTC}+\mathrm{LPV} / \mathrm{r}$ & 1 & 100.0 & 0 & 0.00 & 1 & 0.235 & Ind \\
\hline $\mathrm{AZT}+3 \mathrm{TC}+\mathrm{LPV} / \mathrm{r}$ & 3 & 37.5 & 5 & 62.5 & 8 & & Ref \\
\hline $\mathrm{AZT}+3 \mathrm{TC}+\mathrm{EFV}$ & 0 & 0.0 & 7 & 100.0 & 7 & & \\
\hline $\mathrm{AZT}+3 \mathrm{TC}+\mathrm{NVP}$ & 0 & 0.0 & 36 & 100.0 & 36 & & \\
\hline $\mathrm{TDF}+3 \mathrm{TC}+\mathrm{EFV}$ & 0 & 0.0 & 12 & 100.0 & 12 & & \\
\hline $\mathrm{TDF}+\mathrm{FTC}+\mathrm{EFV}$ & 0 & 0.0 & 32 & 100.0 & 32 & & \\
\hline ARV treatment duration & & & & & & 0.000 & \\
\hline Under 10 years & 20 & 17.4 & 95 & 82.6 & 115 & & Ref \\
\hline 10 years and over & 8 & 88.9 & 1 & 11.1 & 9 & & $38.0[4.5-100]$ \\
\hline \multicolumn{8}{|l|}{ Announcement } \\
\hline Yes & 23 & 33.3 & 46 & 66.7 & 69 & 0.002 & $4.7[1.6-13.4]$ \\
\hline No & 5 & 9.6 & 47 & 90.4 & 52 & & Ref \\
\hline
\end{tabular}


times more likely to be on second-line treatment. The majority of children in this study were either fatherless $(24.0 \%)$, motherless $(20.2 \%)$ or both parents deceased (11.6\%). Similar results were found in the study by M. Sylla et al. [8]. Orphaned children were 3 times more likely to discontinue treatment and 2.6 times more likely to progress to second-line. One of the catastrophic effects of the AIDS pandemic is the multitude of children orphaned by the disease. In our series, the mean age at the start of ARV treatment was $7.6 \pm 4.3$ years with extremes of 0 and 17.6 years. The median was 7.5 years. Similar results were found in a study conducted in Lomé by Atakouma et al. with a mean age of treatment initiation of 5 years 4 months [9]. After 2017, the mean time between the initial examination and the start of ARV treatment was $0.1 \pm 0.2$ years with extremes of 0 and 0.6 years. The median was 0.03 years. Prior to 2017, the mean time from initial examination to ARV treatment initiation was $3.3 \pm 3.6$ years with extremes of 0 and 13 years. Thus, it can be seen that before 2017, the time between diagnosis and the start of treatment was long. Indeed, since the advent of the epidemic, the WHO has recommended CD4 testing before starting ARV treatment, which would be behind this gap between diagnosis and the start of treatment. However, at its major meeting held on 8 June 2016 at the United Nations, the WHO adopted the "Test and Treat" policy [10] which consists of treating all those diagnosed as HIV positive, regardless of their CD4 count, thus reducing the delay and limiting the transmission of the disease. It is the implementation of this policy that explains the short delay between diagnosis and the start of treatment after 2017.

Prior to 2017, children were 15.6 times more likely to be in the second-line.

The mean time from diagnosis to the last contact was 7.6 years with a standard deviation of 4.4 and extremes of 0.04 and 15.3 years. Children were 5.6 times more likely to stop treatment for less than 10 years of follow-up.

In our study, the majority of children, $78.3 \%(\mathrm{~N}=94)$ were on first-line while $21.8 \%(\mathrm{~N}=28)$ of children were on second-line. The average time between the start of treatment and the transition to second-line was 6.2 years. Similarly, the mean age at the start of second-line treatment was 13.7 years. Our results are different from those of the study carried out at Laquintinie Hospital in Douala by Calixte Ida Penda and al who found a mean time to treatment failure of 2.2 years with $73.4 \%$ of the children going on to second-line treatment [11]. Treatment failures are often linked to poor compliance with treatment, hence the need to set up a real therapeutic education programme for patients. More than half of the children, $57.0 \%(\mathrm{~N}=69)$, had been informed of their status. The average age at the time of announcement was $13.9 \pm 1.8$ years. More than half of the children (68.4\%) were under 15 years of age at the time of announcement. The age range found at the time of announcement is similar to that found in countries such as Cameroon (12 - 13 years), Lesotho (10 years), Malawi (11 - 13 years), Uganda (12 years) and Rwanda (11 - 14 years) [12] [13] [14] [15]. Indeed, WHO guidelines recommend that school-age children should be informed of their HIV status; younger children should be informed gradually, taking into 
account their cognitive abilities and emotional maturity, thus preparing them for full disclosure when they are older [16].

In our series, there were 24 cases of therapeutic discontinuation, i.e. $18.6 \%$. The average age at the time of discontinuation was $13.3 \pm 4.3$ years with extremes of 7 and 18.7 years. The average time between the start of ARV treatment and the cessation of treatment was $5.4 \pm 2.3$ years with extremes of 0.8 and 9.1 years. Discontinuation was associated with male gender, orphan status and duration of follow-up. Factors associated with transition to second-line were age group, parental vital status, regimen, duration of ARV treatment and announcement. Orphaned children were 3 times more likely to discontinue treatment and 2.6 times more likely to switch to second-line treatment. Indeed, the presence of parents is very important to administer the drugs or supervise their intake and to watch out for the occurrence of side effects that may lead to treatment discontinuation or non-compliance. Thus, their unfulfilled absence could be a source of poor compliance or therapeutic discontinuation. After 2017, children were 2.8 times more likely to discontinue treatment compared to the risk of moving to a second-line treatment, which was 15.6 times higher before 2017 . When the follow-up duration was less than 10 years, children were 5.6 times more likely to stop their treatment and the risk of failure of the first-line treatment regimen was multiplied by 19.2 when the duration of ARVs was 10 years and more. All of this shows the need for support throughout their treatment. The transition to second-line treatment was higher for those over 10 years old. Indeed, this period, which corresponds to adolescence, is quite complex for children, who become increasingly reluctant to receive treatment, often leading to failure of the first-line treatment? It is therefore necessary to reinforce therapeutic education sessions for better adherence of adolescents but also to carry out studies aimed at elucidating the biological causes of the high rates of virological failure in young subjects. The risk of going on to second-line treatment was multiplied by 4.7 in children who were informed of their status.

This may be related to a refusal to accept the disease. The study by Cissé and al found a $64 \%$ failure rate that was associated with male gender, treatment discontinuation and follow-up by a general practitioner rather than a specialist [17].

This study was conducted at a single management site, which may be a limitation. Extending the study to other management sites with a qualitative analysis could provide a more comprehensive view to identifying factors associated with treatment failure.

\section{Conclusion}

The cohort of HIV-infected children followed up in Guédiawaye remains dominated by adolescents. Orphan status, status announcement and follow-up duration are associated with transition to second-line treatment and treatment discontinuation. It is therefore necessary to set up a transition programme for ado- 
lescents towards an adult cohort in order to improve management and retention in care.

\section{Conflicts of Interest}

The authors declare no conflicts of interest regarding the publication of this paper.

\section{References}

[1] ONUSIDA. Fiche d'information-Dernières statistiques sur l'état de l'épidémie de sida. https://www.unaids.org/fr/resources/fact-sheet

[2] ONUSIDA. Données d'estimation du SIDA au Sénégal 2020. https://www.unaids.org/fr/regionscountries/countries/senegal

[3] Conseil National de lutte contre le SISA du Sénégal. Plan stratégique national de lutte contre le sida 2018-2022.

https://www.cnls-senegal.org/wp-content/uploads/2018/07/PSN-2018-2022-1.pdf

[4] Dirajlal-Fargo, S., Musiime, V., Cook, A., Mirembe, G., Kenny, J., Jiang, Y., Debanne, S., Klein, N. and McComsey, G.A. (2017) Insulin Resistance and Markers of Inflammation in HIV-Infected Ugandan Children in the CHAPAS-3 Trial. The Pediatric Infectious Disease Journal, 36, 761-767.

https://doi.org/10.1097/INF.0000000000001544

[5] Bhattacharya, S.D., Bhattacharyya, S., Chatterjee, D., Niyogi, S.K., Chauhan, N. and Sudar, A. (2014) Risk Factors for Incomplete Immunization in Children with HIV Infection. The Indian Journal of Pediatrics, 81, 850-855.

https://doi.org/10.1007/s12098-013-1049-0

[6] D’Almeida, M., Sagbo, G., Lalya, F., Alao, M.J., D’Almeida, C., Agossou, J., Koumakpai, S. and Ayivi, B. (2013) Profil des enfants infectes par le VIH suivis au Centre National Hospitalier et Universitaire (CNHU) de Cotonou. Mali Médical, 28, 25-29.

[7] OMS. Les jeunes et le VIH [Internet]. WHO. [cité 19 mars 2019]. https://www.who.int/maternal_child_adolescent/topics/adolescence/hiv/fr/

[8] Sylla, M., Dicko-Traoré, F., Oumar, A.A., Traoré, D., et al. (2008) Évaluation de l'observance du traitement antirétroviral chez les enfants infectés par le VIH à Bamako. Archives de Pédiatrie, 15, 1356-1357. https://doi.org/10.1016/j.arcped.2008.04.026

[9] Atakouma, D.Y., Tsolenyanu, E., Gbadoe, A., et al. (2007) Traitement antirétroviral des enfants infectés par le VIH/sida à Lomé (Togo): Premiers résultats. Archives de Pédiatrie, 14, 1178-1182. https://doi.org/10.1016/j.arcped.2007.03.026

[10] OMS. Mettre Fin au VIH/sida D'ici 2030 VIH/sida: Cadre d'action dans la Région Africaine de l'OMS 2016-2020.

https://apps.who.int/iris/bitstream/handle/10665/260473/EndAIDS-fre.pdf

[11] Penda, C.I., Bebey, F.S., Mangamba, D.K., et al. (2013) Échecs thérapeutiques chez les enfants infectés par le VIH en suivi de routine dans un contexte à ressources limitées au Cameroun. The Pan African Medical Journal, 15, Article No. 80.

[12] Vreeman, R.C., Gramelspacher, A.M., Gisore, P.O., et al. (2013) Disclosure of HIV Status to Children in Resource-Limited Settings: A Systematic Review. Journal of the International AIDS Society, 16, Article ID: 18466.

https://doi.org/10.7448/IAS.16.1.18466 
[13] Vaz, L.M.E., Maman, S., Eng, E., et al. (2012) Patterns of Disclosure of HIV Status to Infected Children in a Sub-Saharan African Setting. Journal of Developmental \& Behavioral Pediatrics, 32, 307-315. https://doi.org/10.1097/DBP.0b013e31820f7a47

[14] Namasopo-Oleja, M.S., Bagenda, D. and Ekirapa-Kiracho, E. (2015) Factors Affecting Disclosure of Serostatus to Children Attending Junja Hospital Paediatric HIV Clinic, Uganda. African Health Sciences, 15, 344-351.

https://doi.org/10.4314/ahs.v15i2.6

[15] Mandalazi, P., Bandawe, C. and Umar, E. (2014) HIV Disclosure: Parentla Dilemma in Informing HIV Infected Children about Their HIV Status in Malawi. Malawi Medical Journal, 26, 101-104.

[16] Johnson, J. (2019) Annoncer à un enfant ou un adolescent sa séropositivité au VIH -Boîte à outils. New Horizons, $74 \mathrm{p}$.

https://www.pedaids.org/wp-content/uploads/2019/01/NewHorizonsDisclosureToo $\underline{\text { lkit_FR_Digital.pdf }}$

[17] Cissé, A.M., Laborde-Balen, G., et al. (2019) High Level of Treatment Failure and Drug Resistance to First-Line Antiretroviral Therapies among HIV-Infected Children Receiving Decentralized Care in Senegal. BMC Pediatrics, 19, Article No. 47. https://doi.org/10.1186/s12887-019-1420-z

\section{Abbreviations:}

AZT: Azidothimidine ou zidovudine

3TC: Lamivudine

NVP: Névirapine

TDF: Ténofovir

FTC: Emtricitabine

LPV/r: Ritonavir boosted lopinavir

EFV: Efavirenz

ABC: Abacavir 